\title{
LEADERSHIP STYLE, DISCIPLINE, MOTIVATION AND THE IMPLICATIONS ON TEACHERS'PERFORMANCE
}

\author{
CicihRatnasih* \\ Borobudur University, East Jakarta, Indonesia* \\ fe.unbor17@gmail.com*
}

\begin{abstract}
This study aims to determine the effect of leadership style, discipline, motivation and performance either partially or simultaneously in East Jakarta area.This study is using quantitative method. Total population in the human resource development as the study sample counted as many as 112 respondents. The sampling technique is using purposive sampling.The variables in this study areindependent variable, consist of leadership style, discipline, motivation and performance, and the dependent variable consist. Tests proved that motivation has a positive influence on the performance of teachers. Looking at the calculationsthat have been done the coefficient values obtained is 0.416 and t-count value is 5.984 with a significance level of 0.000 which less than 0.05 , means that this hypothesis accepts Ha and reject Ho, Tests proved that the style of leadership have a positive impact on teacher performance. Judging from the calculations that have been done obtained coefficient value of 0.421 and t-count value of6.446 with a significance value of 0.000, smaller than 0.05. Thus, Ha is accepted and Ho is rejected., The tests proved that the discipline of work has a positive influence on the performance of teachers. Judging from the calculations that has been done obtained coefficient value of 0.151 and the t-count value of 2.055 with a significance level of 0,042 which smaller than 0.05 , means that the hypothesis in this research reject Ho and accept Ha. The results showed that the leadership style, discipline, and motivation partially have significant effect on performance ofaudit quality in East Jakarta area.Leadership style, discipline, motivationsimultaneously have significant effect on performance with coefficient of determination $81.6 \%$.
\end{abstract}

Keywords: Leadership Style, Discipline, Motivation, Teacher Performance

Human resources are the central figure in the organization as well as company. So that the management activity goes well, schools must have teachers who are knowledgeable and highly skilled also efforts to runs the school as optimal as possible so that the performance of teachers will improve.According to Budi Setiyawan andWaridin (2006) teacher's performance is the result or achievement of teacher's work which assessed in terms of quality and quantity based on work standards determined by the organization. A good performanceis the performance that meets the organization standards and promotes the achievement of organization's goals.Good organization is an organization that tries to improve the ability of the human resources.

Leadership style is the behavior norm that is used by a person at the time the person is trying to influence the behavior of others (Suranta, 2002). The leadership style is suitable if the purpose of the company has been communicated and subordinates have received it. A leader must apply a leadership style to 
manage subordinates, because a leader will greatly affect the success in achieving its organization's objectives (Waridin and BambangGuritno, 2005).

Motivation is the drive, effort and desire that exist in people who activate, provide power as well as direct the behavior to carry out tasks well within its work surroundings (Hakim, 2006). Robbins (2006) defines motivation as a process that will determine the intensity, direction, and persistence of individuals in order to achieve the target. Motivation as a process that stems from the strength in terms of physiological and psychological or needs that result in behavioral or encouragement shown on a goal or incentive (Moekijat 2001 in Hakim, 2006).

According to Budi Setiyawan and Waridin (2006), disciplines as the ideal state in support of the implementation of tasks according to the rules in order to support the optimization of the work. One of the conditions that discipline can be implemented in the work environment is, the complete division of labor up to the employee or officer who have the lowest rank, so that everyone aware of what the duties, how to do it, when work is started and completed, what kind of work required, and the one who has to account for the results of the work (Budi Setiyawan and Waridin 2006). Therefore, discipline should be fostered and developed in order to grow order and efficiency. Without a good discipline, do not expect that there will be a leader figure or the ideal teacher as expected by the public and companies. According to Budi Setiyawan and Waridin (2006) and also Aritonang (2005), teacher work discipline is part of teacher performance factor.

Teachers' performance improvement will bring progress for the company to survive in a competitive business environment that is unstable. Therefore, efforts to improve the performance of teachers are the most serious management challenges becausethe success in achieving goals and the survival of the company depends on the quality of the human resources performance that exist therein. High teacher performance is expected by an organization or agency. More teachers who have high performance will increase theoverall agencies' productivity so that it will be able to survive in the global competition. A leader's role is important to achieve the organization or agency goals, primarily concerned with improving the performance of employees in conducting their jobs.

Employee performance is the work that can be accomplished by a person or a group of people within an organization or agency under the authority and responsibilities of each in order to realize the objectives of the organization. But there is a negative factor which greatly degrade the teachers' performance im East Jakarta, including the decrease in the desire of teachers to achieve performance. The decline in performance can have an impact on the expectations desired by the agency may not be realized fully. Teacher in East Jakarta has a high enough motivation to obtain a better individuals well-being but not all of these motivations compensate teachers with maximum performance. Teachers have the awareness to enforce work discipline that can be categorized as minimal, so that between desire and liabilities are not balanced. This can affect the performance generated by the teacher, in other words the performance given by the teacher in East Jakartais not in accordance with agency expectations. From the problems found, then there is a thought to know how the overall factors related to each others and affect the performance of teachers. 
Teachers as human resources, In general, the notion of human resources can be divided into two, which aremacro and micro human resources. Definition of macro human resources is the number of productive age population in a country, while understanding for the micro human resources is more conical to individuals who work at an institution.

Meanwhile, the definition of human resources by experts has a more diverse meaning. According to Malay S.P. Hasibuan (2005:3), human resources are the integrated capabilities of the individual's intellect and physical power.A teacher, for example, as a human resources working in the school office, the ability to think of course should be used to solve all the problems on the job. These activities should also be supported by the physical ability to overcome fatigue when they have to taught in the classroom for about 8 hours dealing with students.Almost the same as Malayu S.P. Hasibuan (2005:3), Rivai Veithzal (2008), defines human resources as a ready, willing and able to contribute efforts in achieving the objectives of the organization. Each organization must have a different purpose, and therefore the ability of the human resources required will be different in each organization.

Although the human resource capacity is flexible, but the words ready and willing from the definition by Rival (2004) should be an underlined point. As well as any human resource capacity will not be able to generate maximum output if these capabilities are not practical or in other words are not ready to use. In addition, the ability will not mean anything if the individual, as the human resources in a company, is not willing to contribute efforts in that place.

According Rivai Veithzal (2008), human resources was described as one of the input element that will be converted into output in the form of goods or services to achieve corporate goals. As an input, human resources can not be a single element, but must be combined well together with other elements such as capital, material, machine, method and also technology.Besied what the experts already states, the terminology of human resources has also been defined in the Indonesian Dictionary. Definition of human resources according to Indonesian Dictionary is the human potential that can be developed for production processes.

Performance is the organizational behavior that is directly related to the production of goods or delivery of services. Information about the organization's performance is a very important thing, it is used to evaluate the performance process done by the organization so far has been in line with the expected goals or not. However, in reality many organizations that are less or even rarely has the information about performance in its organization.Performance as the results of job functions/activities of a person or group in an organization that is affected by a variety of factors to achieve organizational goals within a specific time period (Tika, 2006).

The Objective of Performance Assessment in Mangkunagara (2000: 10), specifically, are as follows:

1. Promote mutual understanding among teachers on performance requirements. 
2. Record and acknowledge the work of a teacher, so that they are motivated to do better, or at least equal to the outstanding achievements of the past.

3. Give the teacher chances to discuss their wishes and aspirations and to increase awareness of career or job entrusted now.

4. Define or redefine future goals, so that teachers are motivated to perform according to their potential.

5. Checking the implementation and development plan that appropriate to the needs of special training, training plan, and then agreed to the plan if there are no rights that need to be changed.

Supporting research conducted by the Rosary (2005) that basicallyleadership style emphasizes in appreciating the purpose of an individual so that later the person will have confidence that actual performance will exceed the performance expectations.

Leadership is the ability of someone to direct, influence, encourage and control other people or subordinates to be able to do some work on his own consciousness and voluntary in achieving a certain goal. The leadership style according to Malayu S.P. Hasibuan:

1. Authoritarian

It is if the power or authority most or absolute remains in the leadership or if the leadership embraces a centralized system of authority. The philosophy of the leader is "subordinate is for the leader or supervisor". Subordinates only served as the executor of decisions that have been set by the leader. Leader considers itself as the smartest and most capable. Direction of subordinate done by giving instructions or orders, threat of punishment, and supervision carried out strictly.

2. Participatory

It is when the leadership is done by persuasion, creating a harmonious cooperation, foster loyalty and participation of the subordinates. Leaders motivate subordinates to feel ownership of the company. The philosophy of the leader is "Leader is for subordinates". Subordinates should participate in giving ideas and considerations in the decision process. The decision still done by the leader with consideration ofsuggestions or ideas provided by subordinates.Leader adheres to the management system (open management) and decentralization of authority.

3. Delegative

It is when a leader delegate authority to subordinates rather complete.Thus, subordinates may take decisions and wisdom freely or flexible in carrying out their work. Here the leader assigns responsibilities for executing the work to subordinates so they can control themselves in completing the work.

Motivation comes from the Latin word "movere" which means "impulse or driving force". Motivation discusses how to give encouragement to the followers or subordinates, in order to work seriously. According to MalayuS.P. Hasibuan (2006) "That motivation is the driving force that creates the work excitement of a person, so that they able tocooperate, work effectively, and integrated with all its resources to achieve satisfaction". Basically an organization or a company not 
only expects the teachers who are able, capable, and skilled but above them that they work hard and willing to achieve an optimal work results.Therefore, work motivation is very important and necessary to achieve high productivity, so the purpose of the company can be achieved.Teachers are able to work with high productivity due to boost from thework motivation.

According to MalayuS.P. Hasibuan (2005: 3), "Motivating is very difficult, because it is difficult for the leader to know the needs and wants required by subordinateswith the results of the work". Work motivation is the motivation that occurs in the work situation and environment contained in an organization or institution. Basically, humans always want things to be fine, so that the driving force or the driving spirit that motivates it works depends on the expectations that would be obtained next. If the expectation can become a reality then the person will tend to be lazy. Based on the discussion about the various terms of work motivation, it covers some components:

a. Needs, this occurs when an individual feels there is no balance between what is owned and what is expected.

b. Encouragement, this is the mental strength to perform acts or activities.

c. The aim, it is what to be achieved by the individual.

According to Marquis and Huston (2000), motivation is divided into two, intrinsic and extrinsic motivation.Intrinsic motivation comes from within the individual; provide an incentive for individuals to become productive. Intrinsic motivation directly related to the ideals of the individual, whereas extrinsic motivation is motivation enhanced through the work environment or the award is given after excellent job. This supporting research conducted by Suharto and Budi Cahyono (2005) suggested that one of the factors that affect performance is the motivation of workers.

According Simamora (1997), discipline is a procedure that corrects or punishes subordinates for violating the rules or procedures.Supporting the research conducted by Budi Setiyawan and Waridin (2006), which revealed that discipline is part of the teacher performance. Work discipline is a tool used by managers to communicate with teachers so that they are willing to changebehaviors as well as an effort to raise awareness and willingness of someone to comply with all company regulations and social norms that applied (Riva, 2004).

Hasibuan (2004) argues that the discipline is an awareness and willingness to comply with all company rules and social norms that applied.Discussion of discipline in the human resources management departs from the view that there is no perfect man to escape from mistakes and wrongs. Discipline is management way to encourage members of the organization to meet the demands of various provisions. This supports the research conducted by Budi Setiyawan and Waridin (2006) which revealed that the work discipline is part of teacher performance factors.

In other words, employee discipline is a form of training that seeks to improve and establish knowledge, attitudes and behavior of teachers so that the teachers can be cooperative with other teachers and to improve its performance. Discipline means if teachers always come and go home on time, do all the work properly, 
comply with all company rules and social norms.In terms of teachers' discipline, rules and penalties are necessary because rules are needed to provide guidance and counseling for teachers to create good order, work spirit, work morale, efficiency and effectiveness of teachers to be increased.

Based on the above understanding, it is concluded that work discipline is an attitude behavior, and act in accordance with the rules written or unwritten, and if violated there will be sanctions for violation.

Hypothesis is a temporary answer to the research problemsformulation, where the research problemsformulation has been stated in the form of sentences (Sugiyono, 2009). The hypotheses in this study are:

Is there any positive influence of leadership style directly on the teachers' performance?, Is there any positive influence of the discipline directly on the teachers' performance?, Is there any positive influence of motivation directly on the teachers' performance?, Is there any positive effect of leadership style and discipline indirectly on the teacher performance throughmotivation asmoderatorvariable?, There is a positive influence of leadership style on the teacher performance motivation?, There is a positive influence of leadership style on the teacher performance discipline?, There is a positive influence between leadership style, discipline, and motivation on the teacher performance.

\section{a. Conceptual Framework}

The description of the above ideas can be clarified through the variable effect of leadership style and discipline towards motivation implicationon teachers' performance in East Jakarta, schematically illustrated as shown below:

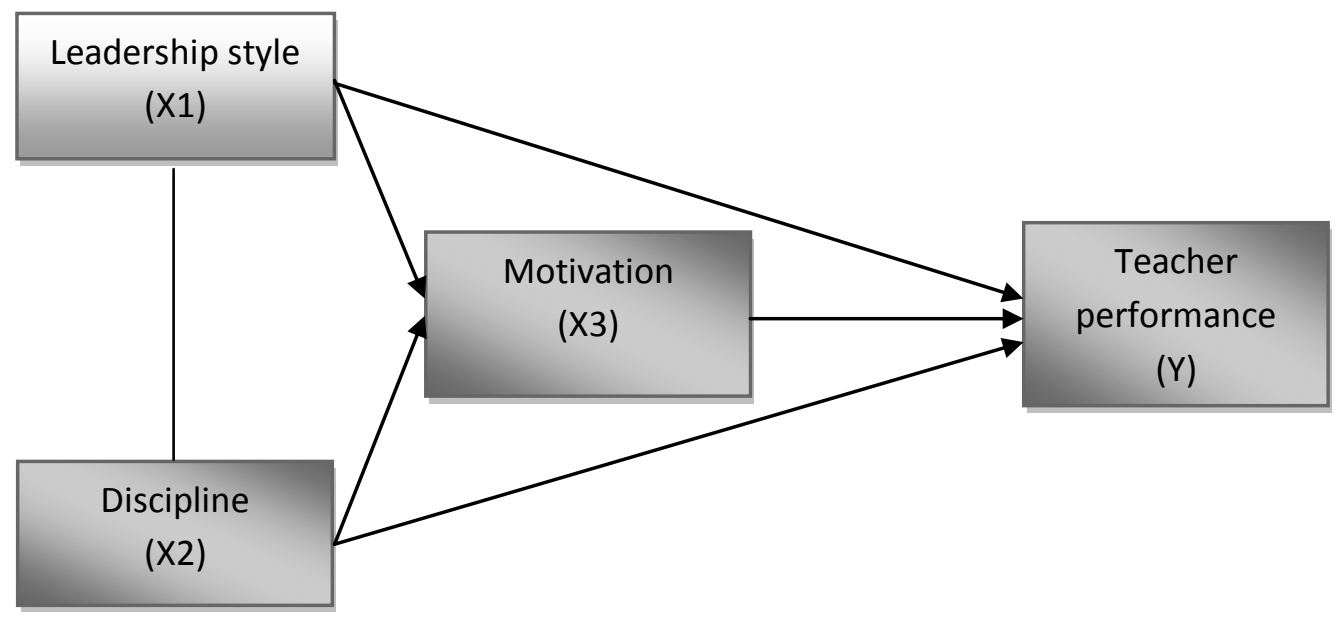

ANALYSIS METHOD

This research use path analysis method. Analysis of pathways known to the path analysis was first developed in the 1920 s by a geneticist, Sewall Wright (Joreskog and Sorbom, 1996; Johnson and Wichern, 1992). Path analysis technique is actually a development of correlation separated into multiple consequencesinterpretations. Furthermore, path analysis has proximity to the 
regression. In other words, multiple-regression is a special form of the path analysis. This technique is also known as a model of causality (causing modeling). This planting is based on the premise that the path analysis allows the user to test the theoretical propositions about causality without manipulating the variables (Sarwono, 2007).

Path analysis of statistical states that for the purpose of forecasting or predicting $\mathrm{Y}$ values on the basis of $\mathrm{X} 1, \mathrm{X} 2, \ldots$, Xivalues, relationship pattern corresponding is the relations that followed the regression model, while to analyze the pattern of causal relationships between variables with the aim to determine the direct and indirect influence, simultaneously or independently, several cause variables against effect variables, then the right pattern is the path analysis model.

Populations in research are a collection of individuals or objects that are properties of general.Arikunto (2010: 173) explains that "population is the entire subject of research" consist of objects or subjects that have certain qualities and characteristics defined by the researchers to be learned and then drawn the conclusions.

Withdrawal or production of sample from the population to represent the population is due to lift the conclusion of researchers as something applicable to the population. Arikunto (2010: 174) says that "Sample is part or representative of the population studied". Further, according to Sugiyono (2010: 81), sample is "part of the number and characteristics possessed by the population"

Validity test was done by comparing the value of r-count with r-table for 5 percentsignificance level of the degree of freedom $(\mathrm{df})=\mathrm{n}-2$, in this case $n$ is the number of samples. If r-count> r-table the question or indicators declared as valid, and vice versa, when the r-count $<$ r-table the question orindicators is declared invalid according to Ghozali(2005). Reliability measurement is done by one-time measuring with SPSS 21 Cronbach Alpha $(\alpha)$ statistical tests.A construct or variable is said to be reliable if the value CronbachAlpha>0.60 (Nunnally in Ghozali, 2005). To ensure that the regression line equation obtained is linear and can be used (valid) to search for forecasting, henceit will be tested bymulticollinearity, heteroscedasticity and normality assumption test.

\section{RESULTS AND DISCUSSION}

a. Respondents Profile

The numbers of respondents in this study were 112 respondents, with the following details:

TABLE I

RESPONDENTS' AGE

\begin{tabular}{|c|c|c|}
\hline Age (Years) & Number of Respondents & Percentage \\
\hline $25-30$ & 44 & 39.29 \\
\hline $35-40$ & 36 & 32.14 \\
\hline $45-50$ & 18 & 16.07 \\
\hline $55-60$ & 14 & 12.50 \\
\hline Total & 112 & 100,000 \\
\hline
\end{tabular}


Based on Table I, it can be seen that for the age of the respondents mostly are aged less than or equal to 30 years as many as 44 people or $39.29 \%$, followed by respondents aged $31-40$ years as many as 36 people or $32.14 \%$. This shows that teachers in East Jakarta mostly are still young and at the highly productive age. This matter shows that the relatively young age, the work spirit owned is still relatively high.

TABLE II

RESPONDENTS' GENDER

\begin{tabular}{|c|c|c|}
\hline Gender & Number of Respondents & Percentage \\
\hline Man & 63 & 56.25 \\
\hline woman & 49 & 43.75 \\
\hline Total & 112 & 100.00 \\
\hline
\end{tabular}

Based on Table II, it can be seen that most respondents were male as many as 63 people compared to women who totaled to 49 people $(43.75 \%)$. This indicates that the male as a larger proportion than female teachers. This is due to the job that requires physical labor, men are generally considered better than woman.

TABLE III

RESPONDENTS' EDUCATION

\begin{tabular}{|c|c|c|}
\hline Education & number of Respondents & Percentage \\
\hline D3 & 25 & \\
\hline S1 & 57 & \\
\hline S2 & 20 & \\
\hline & & 100,000 \\
\hline Total & 112 & \\
\hline
\end{tabular}

Table III shows the data that the numbers of respondents are mostly from the group of S1 educated as many as 57 people or $68.75 \%$ of the total respondents. This suggests that teachers in East Jakarta all have higher education.

\section{b. Data Analysis \\ Hypothesis testing}

TABLE IV

F-TEST RESULT

ANOVA $^{\mathrm{a}}$

\begin{tabular}{|c|c|c|c|c|c|}
\hline Model & $\begin{array}{l}\text { Sum of } \\
\text { Squares }\end{array}$ & $\mathrm{df}$ & $\begin{array}{l}\text { Mean } \\
\text { Square }\end{array}$ & $\mathrm{F}$ & Sig. \\
\hline Regression & 1894.611 & 3 & 631537 & 159175 & $.000 \mathrm{~b}$ \\
\hline residual & 428496 & 108 & 3,968 & & \\
\hline
\end{tabular}




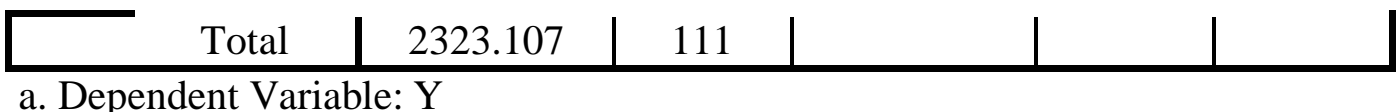

b. Predictors: (Constant), X3, X1, X2

Testing the influence of the independent variables together against the dependent variable is done by using a statistical calculation of F-test.Result show the value of F-count $=159.175$. Using the significance limit of 0.05 , then the significance value is less than 0.05 . This means that the hypothesis that states leadership style, motivation and discipline variables simultaneously have an influence on the performance of teachers is accepted.

\section{T-test}

The t-test was used to test the relationship of each independent variable on the dependent variable separately. In this case, to test the significance of leadership style (X1) towards Performance of Teachers (Y) and to test the significance of Discipline (X2), towards Performance of Teachers (Y)partially.

TABLE V

T-TEST RESULT

Coefficients $^{\mathrm{a}}$

\begin{tabular}{|c|c|c|c|c|c|c|}
\hline & \multirow[t]{2}{*}{ Model } & \multicolumn{2}{|c|}{$\begin{array}{l}\text { Unstandardized } \\
\text { Coefficients }\end{array}$} & $\begin{array}{l}\text { standardized } \\
\text { Coefficients }\end{array}$ & \multirow[t]{2}{*}{$\mathrm{T}$} & \multirow[t]{2}{*}{ Sig. } \\
\hline & & B & Std. Error & beta & & \\
\hline \multirow{4}{*}{1} & (Constant) & -13.026 & 2.527 & & -5.155 & .000 \\
\hline & $\mathrm{X} 1$ & .527 & .082 & .421 & 6.446 & .000 \\
\hline & $\mathrm{X} 2$ & .588 & .098 & .416 & 5.984 & .000 \\
\hline & X3 & .205 & .100 & .151 & 2.055 & .042 \\
\hline
\end{tabular}

a. Dependent Variable: Y

The calculation of the t-count value of the leadership style variablesis 6.446 with a significant value of 0.000 which is smaller than $a=0.05$, Thus Hois accepted or Ha is rejected. With that, the leadership style has a significant effect on the performance of teachers. Furthermore, the calculation of t-count on the motivation variable is equal to 5.984 with significant value 0,000 smaller than $\mathrm{a}=$ 0.05, and thus Ho is rejected or Ha is accepted.

\section{Coefficient of determination}

The coefficient of determination is a quantity that indicates the magnitude of the dependent variable variation that can be explained by the independent variable. In other words, the coefficient of determination is used to measure how far the independent variables in explaining the dependent variable. The coefficient of determination is determined by the adjusted R-square, as can be seen in the following table: 
TABLE VI

ADJUSTED R-SQUARE TEST RESULT

\begin{tabular}{|c|c|c|c|c|}
\hline Model & $\mathrm{R}$ & R Square & Adjusted R Square & $\begin{array}{c}\text { Std. Error of the } \\
\text { Estimate }\end{array}$ \\
\hline 1 & $.903^{\mathrm{a}}$ & .816 & .810 & 1.992 \\
\hline
\end{tabular}

a. Predictors: (Constant), X3, X1, X2

b. Dependent Variable: Y

From the results of regression calculation can be seen that the coefficient of determination (adjusted R2) obtained is 0.810 .

Path analysis

TABLE VII

PATH ANALYSIS RESULT

\begin{tabular}{|c|c|c|c|c|c|c|}
\hline \multicolumn{7}{|c|}{ ANOVA $^{\mathrm{a}}$} \\
\hline & Model & $\begin{array}{l}\text { Sum of } \\
\text { Squares }\end{array}$ & Df & mean Square & $\mathrm{F}$ & Sig. \\
\hline \multirow{3}{*}{1} & Regression & 1894.611 & 3 & 631.537 & 159.175 & $.000^{\mathrm{b}}$ \\
\hline & residual & 428.496 & 108 & 3.968 & & \\
\hline & Total & 2323.107 & 111 & & & \\
\hline
\end{tabular}

a. Dependent Variable: Y

b. Predictors: (Constant), X3, X1, X2

Significant results of variance analysis showed the number of 0.000 . This number is smaller than the critical number assigned, i.e., 0.05 for $95 \%$ confidence level and 0.01 for the $99 \%$ confidence level, so the Ho is rejected and $\mathrm{Ha}$ accepted.

Partial effect of leadership styles on the motivation presented in the following table:

TABLE VIII

T-TEST RESULT

Coefficients $^{\text {a }}$

\begin{tabular}{|cc|c|c|c|c|c|}
\hline \multirow{2}{*}{ Model } & \multicolumn{2}{|c|}{$\begin{array}{c}\text { Unstandardized } \\
\text { Coefficients }\end{array}$} & $\begin{array}{c}\text { standardized } \\
\text { Coefficients }\end{array}$ & \multirow{2}{*}{$\mathrm{T}$} & \multirow{2}{*}{ Sig. } \\
\cline { 3 - 5 } & $\mathrm{B}$ & Std. Error & beta & & \\
\hline \multirow{2}{*}{1} & (Constant) & -13.026 & 2.527 & & -5.155 & .000 \\
& $\mathrm{X} 1$ & .527 & .082 & .421 & 6.446 & .000
\end{tabular}




\begin{tabular}{|l|l|l|l|l|l|}
\hline $\mathrm{X} 2$ & .588 & .098 & .416 & 5.984 & .000 \\
$\mathrm{X} 3$ & .205 & .100 & .151 & 2.055 & .042 \\
\hline
\end{tabular}

a. Dependent Variable: Y

T-test showed significant figure of 0,000 . The figure is smaller than the critical number assigned 0.05 for a confidence level of $95 \%$ or 0.01 for $99 \%$ confidence level so that Ho refused and Ha accepted.

TABLE IX

DURBIN-WATSON TEST RESULT

Model Summary ${ }^{b}$

\begin{tabular}{|c|c|c|c|c|c|}
\hline Model & $\mathrm{R}$ & $\mathrm{R}$ Square & $\begin{array}{c}\text { Adjusted R } \\
\text { Square }\end{array}$ & $\begin{array}{c}\text { Std. Error of } \\
\text { the Estimate }\end{array}$ & $\begin{array}{c}\text { Durbin- } \\
\text { Watson }\end{array}$ \\
\hline 1 & $.903^{\mathrm{a}}$ & .816 & .810 & 1.992 & 2,169 \\
\hline
\end{tabular}

a. Predictors: (Constant), X3, X1, X2

b. Dependent Variable: $y$

Results of the coefficientdeterminationanalysis showed the value of 0.816 , this shows that $81.6 \%$ change in leadership style can be explained by motivation.

TABLE X

LINE 1 ANALYSIS RESULT

\begin{tabular}{|c|c|c|c|c|c|c|}
\hline $\begin{array}{c}\text { Effect } \\
\text { Between } \\
\text { Variables }\end{array}$ & $\begin{array}{c}\text { Coefficient } \\
\text { Beta line }\end{array}$ & $\begin{array}{c}\text { directions } \\
\text { Hub }\end{array}$ & $\begin{array}{c}\text { T-test } \\
\text { Result }\end{array}$ & $\begin{array}{c}\text { F-Test } \\
\text { Result }\end{array}$ & $\begin{array}{c}\text { Determinant } \\
\text { Coefficient }\end{array}$ & $\begin{array}{c}\text { Residual } \\
\text { Coefficient }\end{array}$ \\
$\begin{array}{c}\text { X1 } \\
\text { Towards } \\
\text { X3 }\end{array}$ & .389 & Positive & Significant & Significant & & \multirow{2}{*}{$0.563)^{2}$} \\
\cline { 1 - 4 } $\begin{array}{c}\text { X2 } \\
\text { towards } \\
\text { X3 }\end{array}$ & 0.504 & Positive & Significant & Significant & 0.683 & 0.317 \\
\hline
\end{tabular}

Based on statistical analysis can be seen clearly that partially all independent variables affect the dependent variable. The influences given by the three independent variables are positive means that higher leadership style, motivation and discipline resulted in a higher teacher performance generated. These results are consistent with the hypothesis that is proposed in this research. This result isalso in accordance with the results of previous studies.

\section{CONCLUSION}

From the discussions that have been described, it can be concluded as follows: The results of hypothesis testing have proven there is influence between motivation and performance of teachers. Tests proved that motivation has a positive influence on the performance of teachers. Looking at the calculationsthat have been done the coefficient values obtained is 0.416 and t-count value is 5.984 with a significance level of 0.000 which less than 0.05 , means that this hypothesis accepts $\mathrm{Ha}$ and reject Ho. The results of hypothesis testing have proven there is 
influence between leadership styles with teachers' performance. Tests proved that the style of leadership have a positive impact on teacher performance. Judging from the calculations that have been done obtained coefficient value of 0.421 and t-count value of 6.446 with a significance value of 0.000 , smaller than 0.05 . Thus, $\mathrm{Ha}$ is accepted and Ho is rejected. The results of hypothesis testing have proven there is influence between the disciplines of work with the teacher's performance. The tests proved that the discipline of work has a positive influence on the performance of teachers. Judging from the calculations that has been done obtained coefficient value of 0.151 and the t-count value of 2.055 with a significance level of 0,042 which smaller than 0.05 , means that the hypothesis in this research reject Ho and accept Ha. Motivation has the strongest influence on the performance of teachers in East Jakarta.

\section{REFERENCES}

Algifari, 2000, Regression Analysis: Theory, Case, and Solutions. Yogyakarta: BPFE.

Aritonang, Keke.T. (2005). Compensation, Discipline, and Performance Dale, Robert, D. (1992). Services as Leader. Malang: Gadum Mas

Ghozali, Imam. 2005. Multivariate AnalysisApplications using SPSS. Semarang

Guritno, Bambang dan WARIDIN. 2005. Influence of Teachers'PerceptionsRegarding Leadership Behavior, Job Satisfaction and Motivation on Performance. JRBI.Vol 1. No 1. Hal: 63-74.

Hakim, Abdul. 2006. Analysis of Motivation, Organizational Commitment and Organizational Climate effect on Employee Performance in East Jakarta Area

Handoko, T. Hani. 2003. Management $2^{\text {nd }} E d$. Yogyakarta: BPFE.

Hasibua, Malayu. 2004. Human Resources Management. Jakarta Timur.

Malthis, R.Ldan Jackson. 2001. Human Resources Management. Jakarta Timur: SalembaEmpat.

MasrukhindanWaridin. 2004. Effect of Work Motivation, Job Satisfaction, Organizational Culture and Leadership on Employee Performance. EKOBIS.Vol 7. No 2. Hal: 197-209.

Robbins, Stephen. P. 2006. Organizational Behavior, Indonesian Ed.Jakarta Timur.GRAMEDIA.

RivaiVeithzal. 2004. Human Resource Management for Company.Jakarta Timur.

Setiyawan, Budi dan Waridin.2006. Effect of Teachers' Work Discipline and Organizational Culture on Teacher Performance Semarang. JBRI.Vol 2. No 2. Hal: 181-198.

Simamora, Henry. 1997. Human Resources Management. Yogyakarta.

Sugiyona. 2009. Quantitative Research Methods. Bandung 
Suharto danCahyo. 2005. Effect of Organizational Culture, Leadership and Motivation on Human ResourcesPerformance]. Semarang. JBRI.Vol 1. No 1. Hal: 13-30 